\title{
ASPECTOS DE LA RELIGIOSIDAD POPULAR EN EL REALEJO \\ BAJO DURANTE LA GUERRA CIVIL ESPAÑOLA (1936-1939): \\ ACTOS PROPAGANDÍSTICOS DE LA IGLESIA A FAVOR DEL RÉGIMEN Y LAS FIESTAS DE LA VICTORIA
}

\author{
David Pérez-Siverio González
}

\section{RESUMEN}

Este artículo analiza la influencia de la Guerra Civil española en el pueblo del Realejo Bajo. Se trata de un breve recorrido por los diferentes acontecimientos que este pueblo del norte de Tenerife realizó desde el comienzo del conflicto bélico,, en 1936, hasta su finalización en 1939. Dicho estudio se ha basado fundamentalmente en la investigación de las noticias publicadas en la prensa de la época y sobre todo en el desarrollo de los actos civiles, religiosos y militares que se llevaron a cabo en esta población. Una parte de la historia poco trabajada por los investigadores que puede aportar luz para su conocimiento.

Palabras Clave: Guerra Civil española, Realejo Bajo, falange, Francisco Franco.

\section{ASPECTS OF POPULAR RELIGIOUSNESS IN REALEJO BAJO UNDER THE SPANISH CIVIL WAR (1936-1939): PROPAGANDISTIC ACTS OF THE CHURCH IN FAVOR OF THE REGIME AND THE CELEBRATIONS OF VICTORY}

\section{Abstract}

This article examines the influence of the Spanish Civil war in the village of Realejo Bajo. It's a brief tour of the different events that this village in the North of Tenerife held since the beginning of the war in 1936, until its completion in 1939. This study has been based mainly in the investigation of the news published in the press of the time and above all in the development of civil, religious and military acts that were carried out in this population. A part of the history bit worked by researchers that can bring light to your knowledge.

Keywords: Spanish Civil war, Realejo Bajo, phalanx, Francisco Franco. 


\section{1936, EL AÑO DEL INICIO DE LA GUERRA}

La Guerra Civil española comenzó con el alzamiento de Francisco Franco Bahamonde en julio de 1936. El papel de las islas fue crucial en el conflicto bélico, ya que, desde ellas, se tramó el pronunciamiento militar. El día 15 de dicho mes, el general Franco, comandante general de Canarias, recibe en Santa Cruz de Tenerife la noticia de que el avión Dragon Rapide ${ }^{1}$ que ha de trasladarle al Protectorado español de Marruecos para encabezar el Ejército español de África, el cual estaba previsto que se sublevase el sábado 18 de julio, ya había aterrizado en el aeródromo de Gando de Gran Canaria. Es por tanto que Franco, aprovechando su asistencia al entierro del general Amado Balmes, comandante militar de Las Palmas, que acaba de morir, se trasladó a la isla desde Tenerife por barco, sin levantar sospechas para acudir al sepelio. Estando en la isla, el viernes 17 de julio, conoce que la sublevación en el Protectorado se ha adelantado y que ha comenzado esa misma tarde. Por ello, en las primeras horas del sábado 18 de julio el general partió desde el hotel en el que había pasado la noche hasta la Comandancia Militar de Las Palmas, desde donde proclama el estado de guerra en todo el archipiélago. Los militares sublevados toman los principales edificios oficiales y detienen a los gobernadores civiles de las dos provincias. Ese mismo día 18 de julio se da a conocer en Tenerife un manifiesto redactado por el general Franco en el que justifica el alzamiento militar y que termina con vivas a España y al «honrado pueblo español $»^{2}$. A mediodía el archipiélago canario está bajo el control de los sublevados.

Las noticias acerca de las persecuciones que el bando republicano estaba llevando a cabo en España contra la Iglesia fue el principal motivo de unión de muchos de los cristianos del país para defender la causa franquista. Tras la sublevación militar del 18 de julio de 1936, vino el estallido de la revolución popular, en la cual el pueblo tomó las armas y se sucedieron una serie de actos que el Gobierno republicano no supo controlar. En los meses de julio y agosto existió una oleada de terror anticlerical, se quemaron y saquearon iglesias, se profanaron las imágenes que albergaban los templos y los propios utensilios eucarísticos. Estas noticias llegaban a las islas y en la parroquia de Nuestra Señora de la Concepción del Realejo Bajo se organizó el 30 de agosto de ese año de 1936 una solemne función para «desagraviar al Sagrado Corazón de Jesús por todos los ultrajes y sacrilegios cometidos y profanación de los templos y sagradas Imágenes por los salvajes marxistas» ${ }^{3}$.

Dicha celebración comenzó a las ocho de la mañana, fue oficiada por el R.P. Justino Barrera, cantada la misa del maestro Calahorra por el coro de señoritas y caballeros de la localidad y acompañada por el armónium del profesor Isaac

${ }^{1}$ El avión de la compañía Havilland D.H.89 Dragon Rapide fue un transporte ligero de pasajeros de corto alcance de los años 30. Diseñado como sucesor del D.H.84 Dragon, incluía las alas aflautadas y los cobertores de tren de aterrizaje aerodinámicos del aparato de 4 motores D.H.86 Express.

2 Aróstegui Sánchez, Julio: Por qué el 18 de julio, Ed. Flor del viento, 2006.

3 Gaceta de Tenerife, 12 de septiembre de 1936. 
Aguirre. Se trató de una solemnidad eucarística, tal y como se nos narra, en la cual el párroco aprovechó para exaltar el sentido por el cual se habían congregado en el templo, siendo tan numerosa que se calculó, que más de 500 personas se acercaron para comulgar.

A las diez se procedió a celebrar otra Santa Misa, y a cantar la Letanía de los Santos en rogativas para pedir por todo lo que en estos días críticos está pasando nuestra querida España y nuestra Santa Religión Católica. Después tuvo lugar la Exposición del Santísimo, que estuvo expuesto y manifiesto todo el día, para así visitarlo todos los buenos religiosos que en todo el día hacían la guardia de honor los Adoradores Nocturnos y todas las Cofradías que se relevaban hasta las ocho de la noche, en que terminaron estos cultos con la Novena y la Reserva y con la Bendición del Santísimo Sacramento ${ }^{4}$.

Las celebraciones religiosas estaban acompañadas por actos patrióticos que exaltaban la labor falangista y en concreto a la figura de Francisco Franco, como salvador de la fe católica. Es por este motivo que al finalizar los cultos religiosos se desarrollaban paseos y conciertos en la plaza de la iglesia, algunos organizados por la banda de música La Filarmónica del Realejo Bajo, como sucedió en el marco de los festejos anteriormente citados.

De cuatro a siete La Banda de música «La Filarmónica» de este pueblo dio un rato de expansión a los hijos de esta localidad organizando un animado y concurrido paseo... Habiendo sido aplaudidas todas las obras que ejecutó y particularmente al terminar con el pasodoble «Los voluntarios»" el entusiasmo fué tal, que tuvo que ser repetido, y con vivas a España, al Ejército, a la benemérita Guardia civil y al glorioso general Franco, salvador de nuestra querida España, se terminó este rato tan agradable ${ }^{6}$.

Muchos son los gestos por los cuales observamos la tendencia y el posicionamiento de la mayor parte de la población del pueblo del Realejo Bajo hacia el bando falangista en la Guerra Civil, muy probablemente por ser un núcleo fundamentalmente católico. Uno de los más significativos lo encontramos en la petición

${ }^{4}$ Gaceta de Tenerife, 12 de septiembre de 1936.

${ }^{5}$ Es una marcha-pasodoble de la zarzuela del mismo título, con música de Gerónimo Giménez y letra de Fiacro Yrayzoz. Se estrenó en el Teatro Príncipe Alfonso, el 28 de Julio de 1893. Evocaba la llamada "guerra de África», o "primera guerra de Marruecos", que ocurrió en 1859-60, durante el reinado de Isabel II. Su condición de marcha-pasodoble hizo que inmediatamente la adoptara el Ejército como marcha militar. Además, mantuvo su éxito durante un período muy largo: desde su estreno hasta 1936, y especialmente durante las guerras de Marruecos de 1909-11 y 1921-26. Cuando apareció la radio, era una de las marchas militares que más se escuchaban (muchas veces, por peticiones del oyente). A partir del 18 de julio de 1936, los nacionales empezaron a utilizarla como sintonía, poniéndola en sus emisoras de radio a todas horas. Por ello, el bando rojo dejó de usarla e, incluso, quien la oía se convertía en sospechoso de «fascista».

${ }_{6}^{6}$ Gaceta de Tenerife, 12 de septiembre de 1936. 
que un numeroso grupo hace al corresponsal de la Gaceta de Tenerife, solicitando su intercesión ante la comisión gestora del Ayuntamiento, para que se retiren los letreros de los nombres de las calles. El mismo corresponsal anuncia en su artículo que «la inmensa mayoría de los habitantes de esta localidad se quejan y lamentan, y por ello creemos que con muchísima razón, el hecho de tener que contemplar hasta la fecha las lápidas con rótulos de nombres de personas de varias calles de este pueblo no adictas a la opinión de este vecindario, ni menos al régimen que hoy rige los destinos de nuestra querida España ${ }^{7}$. La intención no es otra que sustituirlos por otros patrióticos, ya que desdice de un pueblo que se siente español».

Uno de los acontecimientos más destacados que se desarrollaron en el año de 1936 se llevó a cabo el 25 de octubre. Tal y como sabemos, octubre es el mes dedicado a la Virgen del Rosario, la cual tenía y sigue gozando de mucha devoción en el Realejo Bajo. En dicha ocasión se celebró de manera extraordinaria una misa de campaña, en la cual la imagen se sacó fuera del templo para improvisar un altar en la plaza, como se nos narra en una crónica publicada en la prensa:

En la escalinata principal de entrada a la plaza, se había improvisado un elegante y artístico altar (foto 1). Al centro, y bajo un hermoso docel se destacaba la Santísima Virgen del Rosario, que en su elegante y bien arreglado trono, presidía el acto. Al terminar el solemne acto del sacrificio de la Misa, que fue oficiada por nuestro, entusiasta y querido párroco interino R.P. Justino Barrera, que fué oída con toda religiosidad, y como en estos solemnes actos no puede faltar la sagrada palabra de un orador que cantara las glorias a la Santísima Virgen, y al grandioso acto que se celebraba, atentamente invitado para hacer el panegírico, ocupó la Cátedra del Espíritu Santo el muy elocuente y culto orador R.P. Optaciano de la Vega, Misionero hijo del Inmaculado Corazón de María, con residencia en el Puerto de la Cruz, que pronunció un elocuente discurso ${ }^{8}$.

Tal y como se narra en la crónica y gracias a una fotografía que conservamos, la imagen se hallaba de manera extraordinaria presidiendo la plaza de la iglesia, portando en el trono la bandera de la victoria en la batalla de Lepanto. Esta acción de celebrar al exterior el culto nos hace entrever el interés de la autoridad religiosa por dotar a la celebración de mayor solemnidad.

Podemos entender que la devoción a la Virgen del Rosario está relacionada con la defensa de la fe católica desde la victoria el 7 de octubre de 1571, de las tropas de la Liga Santa contra el Imperio Otomano. Dicho acontecimiento fue crucial y popularizó el rezo del santo rosario, puesto que el papa Pío $V$ asoció el triunfo de la batalla a la acción intermediadora de la santísima Virgen, en un primer momento con el título de santa María de las Victorias y posteriormente modificado por el papa Gregorio XIII como Nuestra Señora del Rosario. No podemos pasar por alto que este hecho la convirtió en cierta medida en protectora de los ejércitos cristianos.

7 Gaceta de Tenerife, 25 de octubre de 1936.

${ }^{8}$ Gaceta de Tenerife, 25 de octubre de 1936. 


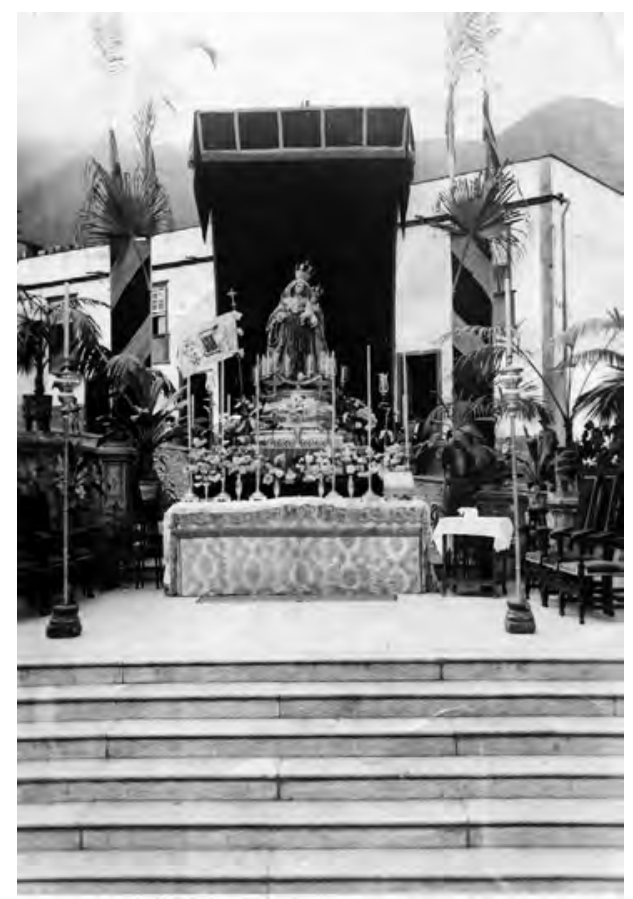

Foto 1. Altar para la celebración de la Virgen del Rosario. Plaza de la iglesia de Nuestra Señora de la Concepción, Realejo Bajo (25 de octubre de 1936). Archivo David Siverio.

Es por este motivo por lo que se decidió en el año del comienzo de la Guerra Civil española exaltar su figura y devoción en el pueblo del Realejo Bajo, pues como había anunciado años antes el obispo de la diócesis, fray Albino, «La Virgen del Rosario se llama también Virgen de la Victoria. Bajo su amparo y con el impulso poderoso de su filial devoción no habrá victoria santa que se nos resista»". Manifestación de dicha creencia fue la elección de la devoción para la exaltación del régimen, puesto que la procesión que partió tras la celebración de la eucaristía hasta el núcleo de San Agustín, donde «fue llevada a hombros por las tropas de acción ciudadana y Falange Española en completo orden y reverencia», se convirtió en un acto de exaltación militar al ejército de derecha. Incluso al finalizar el cortejo procesional «se verificó el desfile de las 5 tropas ante las autoridades, resultando magnífico e imponente», colaborando para ello la banda de música La Filarmónica, la cual «ejecutó varias veces el himno oficial de Falange Española» ${ }^{10}$.

9 Gaceta de Tenerife, 21 de octubre de 1925.

${ }^{10}$ Gaceta de Tenerife, 25 de octubre de 1936. 


\section{1937-1938, EL DESARROLLO DE LA GUERRA}

El año 1937 fue crucial para el avance del bando falangista desde el norte de la península, donde tomaron las principales ciudades. Las noticias de sus victorias en el conflicto se conmemoraban de manera especial y con gran júbilo por parte de los habitantes del Realejo Bajo. En algunas ocasiones los festejos, que probablemente surgirían de manera improvisada, se unían con los habitantes del vecino pueblo de Realejo Alto. No es de extrañar la unificación de las manifestaciones conjuntas por parte de los moradores de dichos pueblos, puesto que en otras ocasiones ya se habían unificado para la realización de actos patrióticos propagandísticos del régimen falangista, celebrando el día de la raza, en el que varios oradores realizaban discursos de carácter patriótico ${ }^{11}$. Volviendo a los festejos organizados por la toma de ciudades, conocemos que la primera que cayó en manos de los franquistas fue la de Bilbao, sede del Gobierno provisional del País Vasco, en el mes de junio.

El sábado último, 19 de los corrientes, fué en este pueblo de Realejo Bajo, un día de gran júbilo, al saberse la grata noticia de la toma de Bilbao por las gloriosas tropas nacionalistas. En la tarde de este día apenas se supo la fausta noticia; las campanas de las iglesias se echaron al vuelo, y empezaran a lanzar cohetes voladores que con sus grandes detonaciones atronaban el espacio. El vecindario se asomaba a sus balcones y ventanas y otros se lanzaban a la calle preguntando qué acontecía; ya enterados de la grata noticia se fué reuniendo todo el pueblo, por los alrededores del Cuartel de Falange, donde seguidamente se organizó una imponente y nutrida manifestación, llevando las banderas nacional y de Falange a la cabeza, con las tropas de milicias y flechas, autoridades, la Banda de música de este pueblo y un numeroso gentío que en pocos momentos invadían las calles, y a las siete partió la numerosa comitiva hacia el Ayuntamiento, y siguiendo por las calles, las cuales

11 Gaceta de Tenerife, 6 de abril de 1937, p. 3. «Realejo Alto y Realejo Bajo, dos pueblos de rancio abolengo y limpia estirpe, situados a flanco de ladera de un borde del estuche que encierra el Valle de la Orotava. Y este dos de mayo, los dos pueblos se vaciaron y se congregaron en el interior y en las afueras del Cinema desde antes de las cuatro de la tarde, ávidos de oír la prestigiosa palabra de los oradores que desde la capital venían a predicarles la buena nueva. Jamás se había visto en los Realejos tal afluencia de gente en un acto parecido: de los campos comarcanos y de las pintorescas calles bordadas dé casas que trepan por la ladera como' si quisieran dominarse unas a otras y poder mirar más lejos, habían acudido las familias enteras; mozas y mozos, chicos y viejos. En el cine no había hueco para una persona más y a través de las puertas se veían cientos de obreros que se aplastaban literalmente para mejor oír. Campos, quien con íácü y clara palabra disertó sobre la fiesta nacional del 2 de mayo, tema obligado, y sobre su significado y simbolismo en los momentos actuales. Le sucedió en el uso de la palabra el culto abogado don Juan Mantl y Martínez Ocampo que tan meritísima labor de propaganda está. Haciendo en esta cruzada patriótica: a mbos escucharon nutridos aplausos. Luego comenzó a hablar don Ramón González do Mesa. Su cálido, verbo fijó la atención de la multitud que ya había comenzado saludándole con una nutrida ovación. Fué el suyo un discurso fogoso y de altos vuelos repleto de erudición al describir aquella gloriosa jornada del 2 de mayo que fue -como dice un gran historiador- «el principio del fin de la epopeya napoleónica.» La gente escuchaba ansiosa y sinceramente entusiasmada, y González de Mesa oyó una salva unánime de aplausos, tan fervorosa y sincera, como acaso pocas veces habrá oído en su vida...». 
lucían todas colgaduras y banderas bicolores como en los principales días festivos; durante todo el recorrido sonaban vivas a Espańa católica, vivas al Generalísimo Franco y vivas al Inolvidable General Mola -¡Presente!- así como vivas al glorioso Ejército libertador de nuestra querida Patria ${ }^{12}$.

Era común, como ya hemos comentado, que dicha aclamación se prolongara hasta el Realejo Alto y allí finalizara la marcha con un discurso que exaltara los valores del bando militar. En esta ocasión dirigió la palabra al público, entre otros, «el joven y jefe de los Flechas de la Orotava don Cándido Acosta, quien fue al terminar su discurso muy felicitado por todos sus amigos ${ }^{13}$. Para las celebraciones de la liberación de Santander los encargados de hablar al público congregado en la plaza de la iglesia fueron el niño Anselmo Fariña Molina; Mario Hernández Siverio, por parte del Realejo Bajo y Pedro Rodríguez Siverio, por parte del Realejo Alto ${ }^{14}$. Por último, para conmemorar la toma de Gijón, el capitán de artillería don Guillermo Camacho y Pérez Galdós se dirigió de manera elocuente al público congregado en la plaza de la iglesia del Realejo Bajo, tras haber marchado desde el cuartel de Falange y la plaza de San Agustín al son de marchas e himnos patrióticos, tirando cohetes y bengalas por la feliz noticia de la terminación de la guerra en el Norte ${ }^{15}$.

Las celebraciones populares no estaban exentas de la participación de la Iglesia y, además, las celebraciones religiosas empiezan a recobrar la libertad que habían perdido en el transcurso del Gobierno de la II República. Tal es así que se hace alusión en los cultos celebrados en honor al Corazón de Jesús del año 1937; «la procesión de la Octava del Corpus, que este año ha sido apoteósica, oyéndose en todo el recorrido cánticos al divino Corazón, así como el Himno Eucarístico, por cantar el cual se multó el año pasado ¡lo que va de un año a otro! al Párroco» ${ }^{16}$.

De dicha solemnidad, nos llama la atención la realización de una alfombra, en la cual observamos una simbología muy característica. Se trata de una representación de la partida del general Francisco Franco desde Canarias. La composición de la misma se divide en tres franjas: en la parte superior, observamos el avión Dragon Rapide, que trasladó al caudillo desde el archipiélago para iniciar la guerra. En la parte central, encontramos la representación de la isla de Tenerife, con la presencia del Teide. Además, cabe destacar que el uso de las líneas diagonales es muy interesante en la alfombra, ya que el sol que se encuentra al fondo proyecta unos rayos que remarcan al avión y le dan mayor importancia. Por último, la franja inferior es la que aporta sentido y explicación a la escena, se trata de la unión de la Iglesia con el régimen. El lema escrito en el tapiz «De Tenerife a la Reconquista de España», nos muestra a Franco como salvador de la fe, que ha sido vilipendiada por el bando

12 Gaceta de Tenerife, 26 de junio de 1937.

3 Gaceta de Tenerife, 26 de junio de 1937.

14 Gaceta de Tenerife, 28 de agosto de 1937, p. 2.

15 Gaceta de Tenerife, 27 de octubre de 1937, p. 2.

16 Gaceta de Tenerife, 16 de junio de 1937, p. 3. 


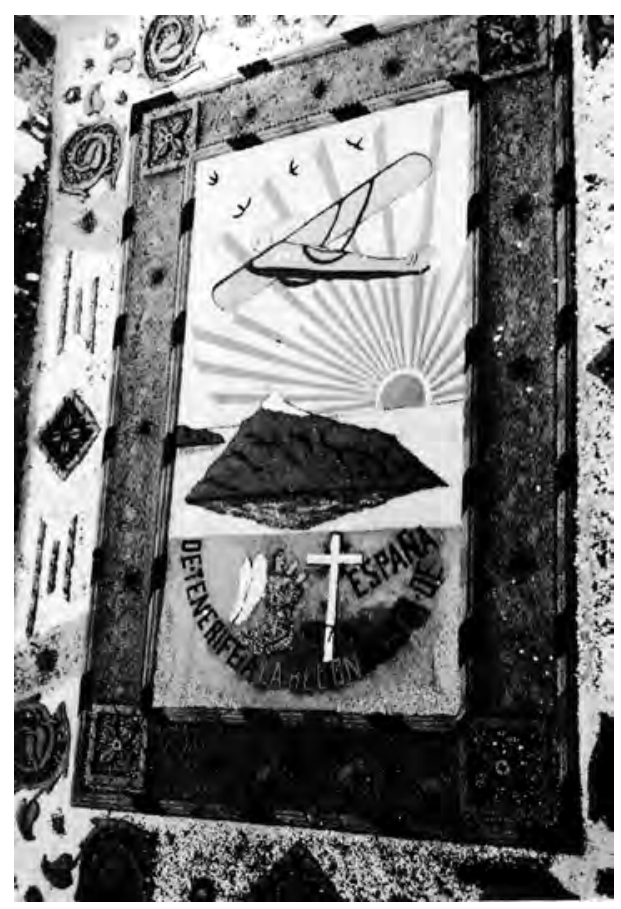

Foto 2. Alfombra de exaltación franquista para la procesión de la Octava del Corpus Christi y del Sagrado Corazón de Jesús, Realejo Bajo (16 de junio de 1937). Archivo David Siverio.

republicano. Esto es reforzado por la cruz central, que es adorada por un ángel, y la fecha alusiva al pronunciamiento militar, «18-7-36» (foto 2).

Suponemos que dicho tapiz fue elaborado por Felipe Siverio Bueno, puesto que aunque aparecen varios nombres de personas que confeccionaron alfombras para dicha procesión en la prensa, la que llama poderosamente la atención por su originalidad y simbolismo es la que realizó Felipe. Tanto fue así que el corresponsal incluye una fotografía del tapiz en la portada del periódico ${ }^{17}$.

Las consecuencias de la guerra se harían notar pronto en la población, por lo que no es de extrańar que esta quisiera que acabase lo antes posible. Ya desde este año de 1937 se fueron desarrollando actos religiosos que pedían, mediante la

${ }^{17}$ Gaceta de Tenerife, 16 de junio de 1937, p. 3. «Entre las alfombras se destacaban por su valor artístico los dos preciosos tapices confeccionados en la plaza de la Iglesia por la Juventud Católica Femenina, y por los inteligentes maestros nacionales don Luis Santana y don Pedro García, así como los que hicieron don José Albelo frente a su casa, y don José García en San Agustín. En esta plaza también confeccionaron alfombras el Cuartelillo de Flechas y don Felipe Siverio Bueno, llamando esta última poderosamente la atención por su originalidad». 
intersección de los principales iconos de la fe, la finalización del conflicto armado y que se trajera de nuevo la paz al país.

La J.C.F. y muchísimas personas continúan haciendo todos los viernes el Vía Crucis de Penitencia, desde la parroquia al Cavario, descalzas en su mayoría, para que el sacrificio sea mayor. Y el rosario de la aurora por las calles adyacentes a la parroquia, para suplicar a Dios la paz tan deseada ${ }^{18}$.

Otro ruego para que Dios intercediera por la pacificación del país fue la celebración de la festividad de Nuestra Señora del Carmen del Realejo Bajo. A esta se incorporó la figura del apóstol Santiago del Realejo Alto, un acontecimiento de exaltación de los valores del nacionalcatolicismo que se impuso en los primeros ańos de la contienda. No es casualidad la unión de dichas imágenes religiosas, porque a pesar de ser las devociones principales del mes de julio, la Virgen del Carmen goza del patronazgo de la Armada española y el apóstol Santiago es símbolo del Ejército español de tierra ${ }^{19}$. Tal y como se narra en la crónica periodística:

Ambas sagradas imágenes formaron en nuestra procesión, lo cual dio margen al predicador, R.P. Antolín Saturnino Fernández para hacer girar su sermón en torno de las ideas de Patria y Religión, presentándonos las negaciones de una y otra por obra del nefasto gobierno del Frente Popular, y su rotunda afirmación, gracias a nuestros heroicos generales y soldados, que han preferido morir antes que perder el patrimonio religioso y patriótico nacional, y ser esclavos de tiranos y traidores, proponiéndonos en la Santísima Virgen del Carmen el estudio protector de nuestras tropas y la salvadora de nuestra Espańa, y recordando que en su día, después de fervorosa Comunión, pasó el Generalísimo a la vecina isla, para desde allí lanzarse a la reconquista de España. Terminada la procesión fué solemnemente despedido y trasladado a su iglesia el glorioso Santiago, como solemnemente había sido recibido en los límites de esta parroquia de Realejo Bajo ${ }^{20}$.

También se llevaron a cabo todo tipo de actos de exaltación militar, como el aniversario de la proclamación como jefe de Estado por parte de $\mathrm{Franco}^{21}$, homenajes

18 Gaceta de Tenerife, 16 de junio de 1937, p. 3.

${ }^{19}$ En la tradición militar de Espańa, el grito de guerra «¡Santiago y cierra, España!» ha sido utilizado por los soldados desde la Reconquista hasta la época moderna antes de cada carga en ofensiva. El significado de la frase es, por una parte, invocar al apóstol Santiago, que según la leyenda se apareció durante la batalla de Clavijo para combatir junto a los cristianos y, por otro, la orden militar cierra, que en términos militares significa trabar combate, embestir o acometer.

${ }^{20}$ Hernández González, Manuel Jesús, «Las fiestas del Carmen de los Realejos, una aproximación histórica», en Hernández García, José Javier (coord.): Vitis florígera, La virgen del Carmen de Los Realejos, emblema de fe, arte e historia, Los Realejos, 2013, pp. 479-480. Extraído de Gaceta de Tenerife, 29 de julio de 1937, p. 3.

${ }^{21}$ Gaceta de Tenerife, 7 de octubre de 1937, p. 3: «A las cinco de la tarde se organizó una gran manifestación organizada por Falange Española Tradicionalista y de las JONS. Falangistas, flechas y numeroso público y Banda de música recorrieron todas las calles del pueblo. Se vitoreó incesantemente a Franco, al ejército salvador y a España». 
a altos mandos del Ejército como fue el caso del teniente coronel don Lorenzo Machado y Méndez Fernández de Lugo ${ }^{22}$, que visitó el pueblo ${ }^{23}$ "cuya actuación en los frentes de combate le ha hecho acreedor a los más calurosos elogios, cuenta en este pueblo con la simpatía entusiasta de todos ${ }^{24}$. En dicho ofrecimiento, festejado en el Ayuntamiento del pueblo, ubicado en la plaza de San Agustín, se honró con todo tipo de actuaciones militares y se le brindó un vino de honor en el propio recinto. Finalizó este con la visita al santuario de la Celestial Señora del Carmen, donde le ofrendaron el homenaje recibido, como exvoto por el triunfo de la España nacional ${ }^{25}$. También se recibían con júbilo las noticias de la llegada de soldados a dicho pueblo por disfrutar de algún permiso. Además, se llevaron a cabo varios funerales por soldados combatientes caídos en guerra, a medida que las noticias de los abatidos iban llegando al pueblo publicadas en los principales periódicos. Algunas de estas exequias se aplicaron por el alma del difunto en el santuario de Nuestra Seńora del Carmen, como aconteció tras el fallecimiento de los «camaradas en Falange Orencio Hernández y Hernández y Agustín Méndez Albelo» ${ }^{26}$ y otros en la parroquia matriz.

El viernes, día 10 de septiembre, a las ocho de la mañana, se celebrará en la Parroquia Matriz de este pueblo una misa por el eterno descanso del camarada Juan Domingo Hernández Hernández, caído gloriosamente por Dios y por la Patria en el frente de Madrid el día 20 de junio próximo pasado, defendiendo la causa Nacionalsindicalista ${ }^{27}$.

Incluso los miembros de la sección de adoración nocturna española del Realejo Bajo se sumaron a la perpetuación de la memoria y la exaltación del martirio y

22 Ingresó en la Academia de Infantería de Toledo el 31 de agosto de 1911 y fue promovido al empleo de alférez el 25 de junio de 1914. Ascendió el 25 de junio de 1916 a teniente y en el mes de agosto de 1920 a capitán. En el año 1936 es comandante, habilitado durante la Guerra de Liberación a teniente coronel y mandando el Regimiento de la 12 División, teniente coronel por méritos de guerra el 1 de abril de 1939. Ascendió a coronel de Infantería el 18 de septiembre de 1942. General de Brigada el 21 de julio de 1952 y general de División honorario por Decreto del 16 de noviembre de 1973. Nombrado hijo adoptivo de Los Realejos en 1958.

23 Periódico Amanecer, 24 de septiembre de 1937, p. 2.

${ }^{24}$ Periódico Amanecer, 2 de octubre de 1937, p. 2. «En el espacioso local se encontraban adecuadamente distribuidos los falangistas, risueños y satisfechos, atentos a las indicaciones de la comisión organizadora del acto, que se esforzaba en qué el público se emplazara lo más cómodamente posible. Por todas partes, banderas á Espańa y de Falange, laureles, palma y flores, música y vivas. El Ejército y a la Falange Española Tradicionalista y de las JONS. Desbordado el espíritu patriótico, los Realejos saludaban en la persona del teniente coronel Machado a la Nueva España y a su Caudillo que, en magnífico retrato, sonriente y majestuoso, presidía el homenaje... Ofreció el homenaje el venerable párroco don Manuel Hernández Reyes, el cual, visiblemente emocionado, puso de relieve el período del Frente Popular, cruzada de desvergüenza, odio y crimen. Enalteció las virtudes heroicas del festejado teniente coronel y terminó suplicando a la Santísima Virgen del Carmen por la vida del Caudillo y sus tropas».

${ }_{25}$ Periódico Amanecer, 2 de octubre de 1937, p. 2.

26 Periódico Amanecer, 20 de agosto de 1937, p. 2.

27 Periódico Amanecer, 9 de septiembre de 1937, p. 2. 
sacrificio que sus compañeros adoradores, soldados alistados, hacían en la guerra. Ejemplo de ello lo hallamos en septiembre de 1937, cuando se realiza una nueva vigilia de la adoración nocturna del Santísimo Sacramento en la cual:

Para dar cumplimiento al Reglamento, será aplicada por el alma de nuestro querido hermano en Cristo don Antonio Fuentes Rodríguez, que falleció en el frente de operaciones, entregando su vida a Dios por la defensa de nuestra querida Patria y por nuestra santa religión católica, por la que siempre se desvivió. Este joven religioso por el amor a su ideal de patriota se había alistado desde el principio del Movimiento glorioso como voluntario en las milicias de Falange, siendo uno de los primeros en ostentar con honra la camisa azul con el escudo le lo Falange; fue de los primeros expedicionarios que salieron para el frente, llevando, por tanto, en dichos frentes 23 meses sin haber disfrutado de ningún permiso en todo este tiempo, hasta que el día 20 de agosto último dejó para siempre este mundo, sin antes ver coronados sus anhelantes deseos de ver liberada por completo toda la zona española, pero Dios así lo dispuso y ya estará disfrutando en el Cielo como otro mártir más de la Patria ${ }^{28}$.

En el siguiente año de 1938, se siguen realizando exaltaciones similares a las de los dos años anteriores. Quizás una de las manifestaciones más llamativas de ese año pudo ser la de la confección y elaboración de las alfombras en honor al Santísimo Sacramento y al Sagrado Corazón de Jesús para la Octava del Corpus. Debemos comprender que en una España dividida, la exaltación de la figura de Cristo fue la bandera del bando nacional y sirvió de protección ante los republicanos. Conocemos que desde las guerras carlistas se había utilizado a la imagen y devoción del Sagrado Corazón como defensa ante el enemigo. No es de extrañar que este símbolo se recuperase en la Guerra Civil, ya que, como hemos recogido en varias ocasiones anteriormente, se trataba de una guerra contra la religión y por lo tanto los católicos del bando nacional utilizaron el detente ${ }^{29}$ como símbolo de protección. Tenemos constancia, por medio de algunos testimonios personales, de que muchos combatientes portaban emblemas o estampas del Corazón de Jesús que sus familias, y especialmente sus madres, les habían entregado para su propia protección. Dicho esto es de entender que los festejos en su honor, en la octava del Corpus Christi, fueran manifestación y exaltación de los valores del bando franquista. Por todo esto las alfombras que se confeccionaban, como había sucedido en el ańo anterior, tenían tintes políticos y militares. En este caso, se sumaron un mayor número de tapices que aludían a esta temática militar, en la que se exaltaba fundamentalmente la figura de Franco y el papel de las islas Canarias en la guerra.

28 Gaceta de Tenerife, 8 de septiembre de 1937, p. 2.

${ }^{29}$ Es un pequeño emblema similar a un escapulario, pero de un solo lado, que se lleva sobre el pecho, con la imagen del Sagrado Corazón de Jesús, signo de amor y de confianza en su protección contra las asechanzas del maligno. Suele llevar las palabas «detente, enemigo, el corazón de Jesús está conmigo». Por lo tanto detiene al enemigo en nombre de Jesús, al demonio y a toda maldad. 
Las alfombras de flores naturales de este año, tres fueron las que principalmente llamaban la atención del visitante: la primera, de difícil estructura. Pero que acreditó el gusto y la destreza de jóvenes, falangistas. Se trataba de componer con flores el nuevo escudo de España, encuadrado entre las dos figuras próceres de nuestro tiempo: Antonio Primo de Rivera y el Generalísimo Franco; y aquellos jóvenes artistas se dieron tan buena mańa, que trasladaron al tapiz, con arte singular, tanto el escudo como los dos bustos de los ilustres personajes. La otra era una evocación patriótica insular, y a través de las siete islas se veía hendiendo las olas y levantando blanca espuma, al crucero de Canarias tremolando al viento la nueva bandera espańola, que las islas le van a regalar y llevando a todos los corazones auras de esperanzas y de próximas victorias. Y todo para honrar al Corazón de Jesús, para que las pisara Jesucristo Hostia, para decirle que le ofrendábamos lo más puro y delicado que teníamos, y así merecer una bendición en favor de nuestra querida Espańa. ¡Que El nos oiga y nos dé pronto el anhelado triunfo! ${ }^{30}$

\section{1939, EL AÑO DE LA FINALIZACIÓN DE LA GUERRA}

En 1939 ya se atisbaba el final de la guerra y es por tanto que muchas parroquias de la isla empezaron a programar actos para la conmemoración jubilosa del final del conflicto. Como hemos sabido, el propio obispo de la diócesis, fray Albino, organizó las celebraciones de la victoria en Santa Cruz de Tenerife, con actos en los que participó la imagen de la Virgen de Candelaria, patrona de Canarias. Eran tantas las ansias de festejar la pacificación del país que los actos se comenzaron a programar mucho antes del final del conflicto, resultando duda el momento de su celebración. Desde que las tropas falangistas tomaron Madrid ya se estaba esperando la fecha, no queriendo adelantarse hasta que el propio Franco entrara de manera triunfal en la capital ${ }^{31}$. Desde que esto sucedió, el 26 de marzo, y se estableció la tan ansiada paz en el país, comenzaron a realizarse por todo el territorio nacional actos para conmemorar el desenlace de la guerra.

Así pues, como ya hemos adelantado se llevaron a cabo las fiestas de la victoria de la patrona de Canarias, en las cuales se trajo la imagen hasta la capital de la isla para conmemorar actos extraordinarios, como la gran misa de acción de gracias en la plaza de la Candelaria de la capital santacrucera. Este acontecimiento sentó precedentes sobre todo para las parroquias del norte de la isla, ya que sus alcaldes participaron de manera activa en dicho acto. Cuando la imagen de la Virgen llegó a la Cuesta esperaban con sus banderas y letreros, ordenados por orden alfabético, para incorporarse a la comitiva que traía a la imagen en su carroza. Probablemente al acto asistieron el párroco de la parroquia de Nuestra Señora de La Concepción de Realejo Bajo, Manuel Hernández Reyes, y el alcalde del Realejo Bajo. Es por

30 Gaceta de Tenerife, 3 de julio de 1938.

31 González Menéndez-Reigada, Albino: La patrona de Canarias y las fiestas de la Victoria, Santa Cruz de Tenerife 1939, p. 127. 


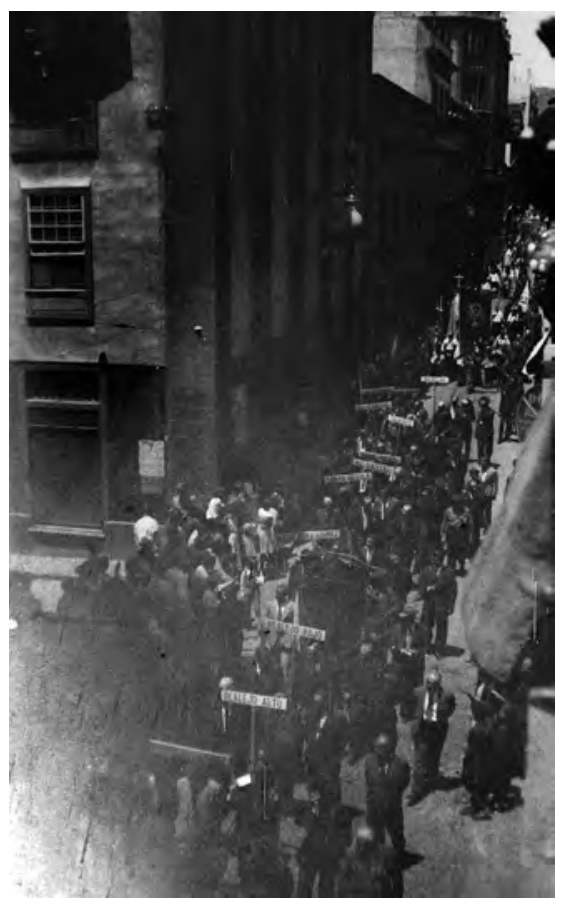

Foto 3. Fiestas de la victoria de la Guerra Civil. El paso de los ayuntamientos por la calle del Castillo en el desfile que traía a la Virgen de Candelaria a la capital (14 de mayo de 1939). Foto: José Pérez Siverio.

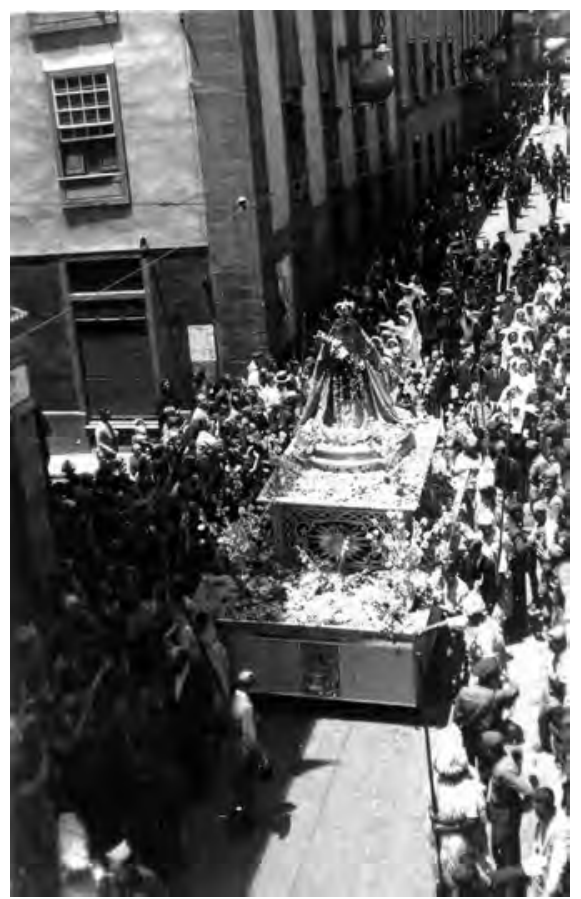

Foto 4. Fiestas de la victoria de la Guerra Civil. Paso de la carroza que transportaba a la Virgen de Candelaria por la calle Castillo (14 de mayo de 1939). Foto: José Pérez Siverio.

tanto que este suceso pudo inspirar a sacerdotes y alcaldes de muchos municipios para conmemorar el dichoso acontecimiento en sus propios pueblos (fotos 3 y 4 ).

Fuera así o no, el caso es que se realizaron numerosas fiestas de la victoria, en las cuales la exaltación más fervorosa siempre fue la procesión magna que muchos pueblos realizaron, sacando en procesión a las imágenes de mayor devoción y las que directamente se relacionaban con los conflictos bélicos o por su patronazgo hacia algún sector militar o por protectorado de la nación. Es por tanto que todos los pueblos del Valle de Taoro quisieron agradecer el triunfo de esta manera. En el Puerto de la Cruz se procesionaron la Santa Cruz, el Gran Poder de Dios y Nuestra Señora de la Peña de Francia ${ }^{32}$. En La Orotova la misa transcurrió en la plaza del ayuntamiento, que estaba presidida por la imagen de la Inmaculada Concepción bajo dosel y el resto de imágenes que formaron parte de este cortejo; el Cristo del

32 Periódico El Día, 17 de mayo de 1939, p. 2. 
Calvario, san Isidro, santa María de la Cabeza, la Virgen de Lourdes, el Sagrado Corazón de Jesús, la Virgen del Carmen y San Juan bautista ${ }^{33}$.

A su vez el pueblo de Realejo Alto hizo lo propio y llevó a cabo una celebración durante los días 14 y 15 de mayo en la cual hubo repiques de campanas, dianas floreadas, lluvias de cohetes desde la torre y lo más importante, una magna procesión con las principales imágenes devocionales del pueblo; «San Francisco de Asís, San Benito, Santiago Apóstol, Santa Bárbara, la Virgen de las Angustias, de Palo Blanco, la Virgen de las Mercedes, de la Cruz Santa, Sagrado Corazón de Jesús y Virgen de los Remedios, Patrona de este pueblow ${ }^{34}$.

En cuanto a los actos programados en el Realejo Bajo, sabemos que se organizaron animados festejos durante los tres días, 3, 4 y 5 de junio y que se trató de una combinación de actos festivos y religiosos, comenzando el «día 3 a las 7 de la tarde, como iniciación de los actos, repique general de campanas, gran cantidad de voladores y elevación de globos con fuegos artificiales» ${ }^{35}$.

Días antes de su realización, aparecen anunciados en prensa de la siguiente manera:

El próximo domingo, día 4, se celebrarán en este pueblo grandes festejos por la feliz terminación de la guerra y la victoria de nuestro Caudillo, Generalísimo Franco. Entre otros números del programa, que pronto se dará a conocer, figurará; una solemne misa en honor de los Caídos, seguida de magnífica procesión en La que figurarán las imágenes de los siguientes barrios: Icod el Alto, Tigaiga, El Socorro, San Vicente y Nuestra Señora del Carmen, del barrio de San Agustín. Por la, noche se celebrará un gran verbena, a la que acudirá la juventud de este pueblo luciendo el traje típico de Tenerife ${ }^{36}$.

Se trató de una manifestación muy inusual, ya que, como se recoge, hasta el templo eclesial llegaron todas las imágenes de mayor devoción procedentes de todas las ermitas de la jurisdicción parroquial. De esta manera la participación de los habitantes de todos los barrios estaba asegurada, puesto que a manera de comitiva se organizaron grupos de personas en dichas ermitas para portar y acompañar a sus patrones hasta el templo matriz del Realejo Bajo. Tal y como podemos extraer de la crónica periodística, entendemos que las imágenes de mayor lejanía y debido a la complicación de su recorrido, llegaron en las primeras horas del segundo días de los festejos.

Día 4 - A las 8 de la mańana, misa rezada, con Comunión general. A las 9 llegarán a este pueblo las imágenes de Nuestra Señora del Buen Viaje, de la parroquia del pago de Icod el Alto; la Virgen del Socorro y San Pedro, del pago de La Rambla. A

33 Periódico El Día, 20 de mayo de 1939, p. 2.

34 Álvarez García, Jerónimo David: Las fiestas patronales de Realejo Alto en honor a Nuestra Señora de Los Remedios (1907-1959). Los Realejos, 2017, p. 95. Extraído del periódico El Día, 14 de mayo de 1939, p. 5.

35 Periódico El Día, 3 de junio de 1939, p. 2.

36 Periódico El Día, 2 de junio de 1939, p. 2. 
las 3 de la tarde, concierto por la banda de música de este pueblo y probablemente otra forastera. A esta hora se congregarán gran número de niñas y niños y señoritas ataviadas con el traje típico del país, y viarias carrozas desfilarán por las calles y plazas de este pueblo, y se elevarán varios globos ${ }^{37}$.

Como hemos venido anunciando la manifestación más relevante se llevó a cabo

A las 5 de la tarde, la procesión magna con las imágenes, de San Miguel, San Sebastián, San Vicente, San Pedro, la Virgen del Socorro, la Purísima Concepción, del barrio de Tigaiga. Nuestra Señora del Buen Viaje, del pago de Icod el Alto; el Sagrado Corazón de Jesús, la Purísima Concepción, Patrona de este pueblo, y Nuestra Señora del Carmen, Patrona de la Marina Española, que recorrerán varias calles, las que se hallarán engalanadas y alfombradas con flores. Al regreso de la procesión a la parroquia, se cantará un solemne Te-Deum, y a continuación predicará el elocuente orador sagrado don Heraclio Sánchez Rodríguez ${ }^{38}$. A estos actos asistirán las autoridades locales, Hermandades y Congregaciones religiosas, y Falange Masculina y Femenina de este pueblo ${ }^{39}$.

Dicha manifestación de fe jamás ha sido vista en el pueblo del Realejo Bajo, nunca que sepamos, una solemnidad ha aglutinado a tantas imágenes en una misma procesión. Se agruparon varias advocaciones de la Virgen y todo tipo de santos que han sido fundamentales para comprender la devoción popular de este pueblo. La continuación de las fiestas se llevó a cabo «a las 9 de la noche, con una gran verbena en la plaza del General Franco, la que se hallará artísticamente engalanada, quemándose en todos estos actos gran cantidad de cohetes» ${ }^{40}$. Por último, la finalización de dichos festejos se llevó consolidó al día siguiente, comenzando a las 11 de la mañana con un solemne funeral en la parroquia, ante el Altar de la Patria, por el eterno descanso de los caídos del pueblo durante la guerra; además, a dicha misa se invitó a los familiares de los mismos. Ese mismo día a las 5 de la tarde, las imágenes regresaron a sus santuarios para así finalizar las celebraciones de las fiestas de la victoria.

Hemos podido comprobar a lo largo de estas páginas cómo fue el trascurso de este conflicto militar, uno de los episodios más tristes de la historia española, un momento de convulsión política que sin lugar a dudas marcó de manera singular a todos los pueblos del territorio nacional y por tanto al devenir del Realejo Bajo. Y que dio lugar a los ańos más duros de la historia de Espańa, la posguerra.

Recibido: 22-03-2018, ACEPTADo: 10-04-2018

37 Periódico El Día, 3 de junio de 1939, p. 2.

38 (1887-1946) Presbítero, canónigo magistral de la santa iglesia catedral de La Laguna y profesor de Derecho Canónico en la Universidad de La Laguna. Elocuente orador sacro y hombre intelectual.

39 Periódico El Día, 3 de junio de 1939, p. 2.

${ }^{40}$ Periódico El Día, 3 de junio de 1939, p. 2. 
